\title{
Effect of Super Absorbent Polymer and Irrigation Deficit on Water Use Efficiency, Growth and Yield of Cotton
}

\author{
Hamid-Reza FALLAHI ${ }^{*}$, Reza TAHERPOUR KALANTARI ${ }^{2}$, \\ Mahsa AGHHAVANI-SHAJARI ${ }^{3}$, Mohammad-Ghasem SOLTANZADEH ${ }^{2}$
}

\author{
${ }^{1}$ University of Birjand, Faculty of Agriculture, Birjand, Iran; Hamidrezafallabi@birjand.acir ("corresponding author) \\ ${ }^{2}$ University of Birjand, Sarayan Faculty of Agriculture,Sarayan,Iran; Re.taherpour@gmail.com; Ghasem2301@gmail.com \\ ${ }^{3}$ Ferdowsi University of Mashhad, Faculty of Agriculture, Mashhad, Iran; Mahsa.aghhavanishajari@stu.um.ac.ir
}

\begin{abstract}
Sustainable use of water resources in agriculture is a necessity for many arid countries. In order to investigate the effect of water deficit, irrigation after 120 (control), 155 (moderate water stress) and $190 \mathrm{~mm}$ (sever water stress) pan evaporation and super absorbent polymer rates $(\mathrm{SAP})\left(0,30,60\right.$ and $\left.90 \mathrm{~kg} \mathrm{ha}^{-1}\right)$ on growth, yield and water use efficiency of cotton, an experiment was conducted as split plot based on a randomized complete block design with three replications. Moreover, the effect of water quality (distilled water and solutions of $0.25,0.5$, $0.75,1$ and $1.25 \% \mathrm{NaCl}$ ) was investigated on water holding capacity by SAP. Results revealed that moderate water stress (irrigation intervals of aprox. 15 days) along with $60 \mathrm{~kg} \mathrm{ha}^{-1} \mathrm{SAP}$ application was the best treatment in terms of growth and yield indices of cotton. The results for plant height, plant dry weight, boll number per plant and fiber yield in this treatment were 16, 28, 42 and 10\% higher than control treatment, respectively. Water deficit and SAP application improved the water use efficiency (WUE) of cotton. The amount of WUE in moderate water stress treatment along with consumption of 60 or $90 \mathrm{~kg} \mathrm{ha}^{-1}$ SAP was $26 \%$ higher than for control treatment. In addition, water holding capacity by SAP in distilled water treatment was 7 times higher than in the case of $1.25 \% \mathrm{NaCl}$ solution. The overall results showed that irrigation deficit and SAP application are two appropriate strategies for crop production in areas affected by drought stress, especially if low saline water sources are used.
\end{abstract}

Keywords: drought stress, fiber, lint, sodium chloride, water deficit

\section{Introduction}

Cotton (Gossypium birsutum L.) is a woody, perennial, indeterminate plant with the $\mathrm{C}_{3}$ photosynthesis pathway, grown in warm and some temperate climates for fiber and, with less importance, for oil production. This crop is cultivated as an annual plant and is grown around the world from the tropics to regions with temperatures as high as 42 ${ }^{\circ} \mathrm{C}$. The major cotton producers are China, India, Pakistan, United States, Uzbekistan, Brazil and Turkey (Stewart et al., 2010; Evett et al., 2012; Dai and Dong, 2014). Cotton is a salt and drought tolerant plant and consequently is suitable for arid and semi-arid regions. In areas with low rainfall, cotton yields increases with irrigation application over the range of 600 to $900 \mathrm{~mm}$. However, excessive water availability promotes its vegetative growth and suppresses reproductive growth. Overly water provided during flowering, boll growth and fiber development stages, will result in rapid and continued vegetative growth and dropping of early flowers and young bolls. Nevertheless, water stress during the reproductive stage, if severe enough, also causes abscission of flowers and bolls (Evett et al., 2012).
Reduced availability of water resources in many arid countries such as Iran, particularly in response to the indiscriminate harvesting of water reservoirs and climate change, has created real concerns (Razavi and Davary, 2014). Therefore, water scarcity is a serious threat for food production and security for millions of people in arid and semi-arid regions. Concurrent with the increase in world population, the arable lands per capita and water availability will decrease. Therefore, water resources including rainfall and irrigation water must be used more efficiently and water productivity should be increased (Zhang, 2003; Dabhi et al., 2013). Where water resources are limited, the farmers and researchers' goal must be maximizing net income for water used per unit, rather than per land unit. Hence, currently the emphasis is on the concept of water productivity, namely the yield or net income per unit of water used in evapotranspiration (Fereres and Soriano, 2007).

Deficit irrigation is one of the main strategies for the optimization of water use in irrigated lands, where crops are irrigated less than the requirement. As a result, some of the plant yield is reduced, but more land can be brought under cultivation by saving in water consumption and therefore,

Received: 11.06.2015. Received in revised form: 30.06.2015. Accepted: 08.09.2015. Published online: 24.09.2015. 
Table 1. The main climatic indices during the experiment

\begin{tabular}{lccccc}
\hline $\begin{array}{l}\text { Growth months (Local months and } \\
\text { their A.D equivalents) }\end{array}$ & $\begin{array}{c}\text { Precipitation } \\
(\mathrm{mm})\end{array}$ & $\begin{array}{c}\text { Evaporation } \\
(\mathrm{mm})\end{array}$ & $\begin{array}{c}\text { Monthly } \\
\text { average } \\
\text { humidity }(\%)\end{array}$ & $\begin{array}{c}\text { Monthly } \\
\text { sunshine } \\
\text { hours }\end{array}$ & $\begin{array}{c}\text { Average of } \\
\text { minimum } \\
\text { temperatures }\left({ }^{\circ} \mathrm{C}\right)\end{array}$ \\
\hline Khordad (22 May-21 Jun) & 0 & - & 18 & 336.5 & 20.5 \\
Tir (22 Jun-22 Jul) & 0 & 461.7 & 14 & 381.9 & 22.8 \\
Mordad (23 Jul-22 Aug) & 0 & 425.2 & 13 & 369.9 & 22.3 \\
Shahrivar (23 Aug-22 Sept) & 0 & 329.0 & 15 & 350.6 & 18.4 \\
Mehr (23 Sept-23 Oct) & 0 & 238.0 & 23 & 288.6 & 15.0 \\
Aban (23 Oct-22 Nov) & 26 & 94.2 & 45 & 265.8 & 37.3 \\
Azar (22 Nov-22 Dec) & 11 & - & 48 & 220.2 & 05.2 \\
\hline
\end{tabular}

Table 2. The main properties of superabsorbent polymer (potassium polyacrylate and polyacrylamide copolymers)

\begin{tabular}{|c|c|c|c|}
\hline Index & Description & Index & Description \\
\hline Appearance & White granule & Grain size $(\mathrm{mm})$ & $0.5-1$ \\
\hline Density $\left(\mathrm{g} \mathrm{cm}^{-3}\right)$ & $1.1-1.5$ & $\mathrm{pH}$ & 7.4 \\
\hline $\begin{array}{l}\text { The actual capacity of absorbing tap water } \\
\text { (g.g } \text { g }^{-1} \text { within an hour) }\end{array}$ & 112 & Maximum durability (year) & $7^{*}$ \\
\hline Moisture content (\%) & 11.6 & $\mathrm{EC}(\mu \mathrm{m})$ & 1754 \\
\hline
\end{tabular}

greater benefit can be achieved. In addition, appropriate use of deficit irrigation can increase water use efficiency (Akbari, 2011). Deficit irrigation is a suitable and sustainable production solution, especially in dry regions of the world. By increasing irrigation intervals, reducing the amount of water used in each irrigation time or by limiting water consumption to drought-sensitive growth stages, this practice aims to maximize water productivity and to stabilize yields. This strategy is a successful way for increasing water productivity in different crops without causing severe decline in growth and yield of plant. However, considering that drought tolerance varies by genotype and phenological stages, deficit irrigation requires detailed understanding of crop response to drought stress (Geerts and Raes, 2009; Ghorbani-Nasrabad and Hezarjaribi, 2010).

It has been reported that cotton is a sensitive plant to irrigation timing and quantity through different growth stages. In north Iran condition, of providing $70 \%$ of water requirement of cotton, it was obtained higher water use efficiency $(16.7 \%)$ and only $4.7 \%$ yield reduction than with full irrigation regime (Ghorbani-Nasrabad and Hezarjaribi, 2010). In another study on cotton in north of Iran it was reported that full irrigation is not necessary for this plant and irrigation with $75 \%$ of water requirement could be sufficient (Akbari, 2011). Results of an experiment on cotton revealed that use of limited drip irrigation regime with $50 \%$ of water requirement leads to a moderate decrease in yield, without considerable negative impact on the fiber quality and had remarkable benefits in terms of water saving and water use efficiency (Papastylianou and Argyrokastritis, 2014).

Uncertainty of precipitation and increased temperatures in low rainfall areas is prominent throughout the world, which encourages efficient water conservative by soil amendments such as plant residue, zeolite and synthetic super absorbent polymers (SAP) (Dabhi et al., 2013; Najafinezhad et al., 2014). In dry areas, water scarcity is the main limiting factor for crop production. Thus, the use of SAP may effectively increase plant growth by improving nutrient use efficiency and water retention into the soil. These polymers are soil conditioners, developed to aid plant establishment and growth in drought condition (Woodhouse and Johnson, 1991; Eneji et al., 2013; Mazen et al., 2015). SAPs are highly hydrophilic due to low cross-links in their structure and have great potential for soil restoration and storing water for plant growth (Keshavarz et al., 2012). So far, the positive effects of SAP application on growth, yield and water use efficiency in many crops such as maize (Eneji et al., 2013; Mazen et al., 2015), pear millet (Keshavarz et al., 2012), barely and lettuce (Woodhouse and Johnson, 1991) has been reported. Most of these studies have concluded that SAP reduces water stress during prolonged drought stress condition and during irrigation intervals (Dahbi et al., 2013). However, water absorbing ability of SAPs depends on many factors, including irrigation water quality. So that, their efficiency might be reduced in the case of saline irrigation water (Rahbar and Banedjschafie, 2009; Rousta et al., 2013).

A large part of Iran has arid and semi-arid climate and is facing high water scarcity due to low precipitation. Nevertheless, excess water is often used for the irrigated crops and water use efficiency is low in the country. Accordingly, crops such as cotton, which is cultivated in many parts of the country, are facing the risk of removing from the cropping pattern in these areas, due to the fact that cotton uses more water than other historical native crops. Therefore, improving the water use efficiency is required for stable cotton production in the country. Hence, the aim of this study was to investigate the effects of deficit irrigation and SAP application on growth, yield and water use efficiency of cotton, in arid regions of Iran. In addition, in arid areas minimal water resources also have high levels of salts which could affect the efficacy of SAPs. Therefore, simulation of SAP efficiency at different levels of salinity was of the other objectives in this study.

\section{Materials and Methods}

\section{Experimental site}

This research was conducted at Sarayan $\left(33^{\circ} \mathrm{N}, 58^{\circ} \mathrm{E}\right.$ and 1,450 masl) in South Khorasan province, Eastern part of Iran. The climate of Sarayan is characterized as semiarid and the average annual precipitation and mean annual temperature are $150 \mathrm{~mm}$ and $17^{\circ} \mathrm{C}$, respectively. Climatic conditions of research station during the experiment period are shown in Table 1. 
Table 3. Some qualitative properties of the irrigation water

\begin{tabular}{cccccccc}
\hline $\mathrm{EC}(\mu \mathrm{m})$ & $\mathrm{pH}$ & $\mathrm{TDS}(\mathrm{ppm})$ & $\begin{array}{c}\mathrm{Ca}^{2+}(\mathrm{ppm} \text { as } \\
\left.\mathrm{CaCo}_{3}\right)\end{array}$ & $\mathrm{Mg}^{2+}\left(\mathrm{ppm}\right.$ as $\left.\mathrm{CaCo}_{3}\right)$ & $\mathrm{Na}^{+}(\mathrm{ppm})$ & $\mathrm{K}^{+}(\mathrm{ppm})$ & $\mathrm{Cl}^{-}(\mathrm{ppm})$ \\
\hline 1300 & 7.81 & 8510 & 48 & 51.5 & 156.4 & 0.45 & 170.4 \\
\hline
\end{tabular}

\section{Experimental treatments}

\section{Field experiment}

In order to study the effects of deficit irrigation and chemical super absorbent polymer (SAP) on vegetative and reproductive growth indices and water use efficiency of cotton, a one year experiment was conducted at Sarayan Faculty of Agriculture, University of Birjand, Iran during 2013-2014. The experiment was evaluated as split plot based on a randomized complete block design, with three replications. Experimental factors were consisted of water deficit: irrigation after 120 (control), 155 (moderate water stress) and $190 \mathrm{~mm}$ (sever water stress) evaporation from pan, as main factor, and SAP application $\left(0,30,60\right.$ and $\left.90 \mathrm{~kg} \mathrm{ha}^{-1}\right)$ as sub factor. Almost $600 \mathrm{~m}^{3} \mathrm{ha}^{-1}$ water were used in each irrigation round, after evaporation occurred at the rates of required $(120,155$ and $199 \mathrm{~mm}$ ) for each irrigation treatment. The conventional irrigation interval for cotton in Sarayan is one time in 12 days ( 120 mm pan evaporation). Therefore, 155 and $190 \mathrm{~mm}$ pan evaporation treatments (approximately equal to irrigation intervals of 15 and 18 days) were selected as irrigation deficit. The consumed SAP was made of potassium polyacrylate and polyacrylamide copolymers. The main properties of SAP are presented in Table 2.

\section{Laboratory experiment}

Water holding ability of SAP is strongly influenced by the type and concentration of ions in the irrigation water. Therefore, the amount of this index was measured within the first hour of moisture supply in six water quality treatments including solutions of 0 (distilled water), $0.25,0.5,0.75,1$ and $1.25 \% \mathrm{NaCl}$. Moreover, grain size (by micrometer), $\mathrm{pH}$ (by $\mathrm{pH}$ meter), $\mathrm{EC}$ (by EC meter) and density of SAP were determined (Table 2). The ability of the superabsorbent polymers for water retaining decreased dramatically in saline waters, especially in response to divalent salts (Rahbar and Banedjschafie, 2009). Therefore, the amounts of qualitative indices of irrigation water such as monovalent and divalent ions concentration are presented in Table 3.

\section{Agronomicpractices}

Soil preparation was done in 10 April and seed planting of cotton using Khordad cultivar was applied in 20 June. About 30 ton per hectare cow manure was used during seedbed preparation practices. Also, $240 \mathrm{~kg} \mathrm{ha}^{-1}$ urea (80 kg pre planting and $160 \mathrm{~kg}$ during vegetative growth period) and $200 \mathrm{~kg} \mathrm{ha}^{-1}$ phosphate (preplanting) were used. Seed sowing was performed manually, using pile method ( 4 seeds per pile) in $3 \times 3 \mathrm{~m}$ plots. The distances between plants after plant thinning in 20 July, were adjusted to $60 \times 25 \mathrm{~cm}$, therefore plant density was 83,000 plants per hectare For SAP application, the material was mixed properly with soil using manual plough, to a depth of $30 \mathrm{~cm}$. All plots were irrigated immediately after seed sowing in 22 Jun as well as in 1 July and then the irrigation intervals treatments were exerted in each plot until the end of the growth season. At the end of the growing season all plots were irrigated (around $15 \mathrm{Oct}$ ) and then irrigation was stopped until the end of cotton picking period. Irrigation frequencies in 120, 155 and $190 \mathrm{~mm}$ pan evaporation treatments (equal to $~ 12,15$ and 18 days irrigation intervals) to the end of the growing season were 11,9 and 8 times, respectively. The amount of water used in each irrigation round was $600 \mathrm{~m}^{3} \mathrm{ha}^{-1}$. Accordingly, the amount of water used during growth season was determined using the amount of water used in each irrigation time $x$ irrigation frequencies in each treatment. Finally, water lùse efficiency was calculated using the following equation. Also, the harvesting of cotton was done in three times at 27 Oct, $10 \mathrm{Nov}$ and 17 Nov.

$W U E\left(\mathrm{~kg} \mathrm{~m}^{-3}\right)=\frac{\text { Cotton yield }\left(\mathrm{kg} \mathrm{ha}^{-1}\right)}{\text { Water used during growth season }\left(\mathrm{m}^{3} \mathrm{ha}^{-1}\right)}$

\section{Measuredindices}

For measuring vegetative and reproductive growth (yield components) indices of cotton, five plants were selected randomly in each plot at 20 Oct. After that, some indices including plant height $(\mathrm{cm})$, plant dry weight $(\mathrm{g})$, number of lateral branches per plant, number of reproductive branches per plant, mean boll weight (fiber + seed + capsule), boll number per plant, fiber yield per boll and yield per plant were measured. Moreover, the amount of chlorophyll index was determined using SPAD meter model 502 plus Konica. For determining the amounts of yield per hectare the remaining plants (19 plants per plot) were used after elimination of the border effect (two marginal rows and a half meters from each side of three middle rows) and their cotton was picked in three harvests. Finally, harvest index was calculated using the equation:

Harvest index $=\frac{\text { Economical yield }(\text { lint }+ \text { seed })\left(\mathrm{kg} \cdot \mathrm{ha} \mathrm{a}^{-1}\right)}{\text { Biological yield }(\text { vegetative body }+ \text { lint }+ \text { seed })\left(\mathrm{kg} \cdot \mathrm{ha^{-1 }}\right)}$

Dataanalysis

Statistical analysis of the experimental data was made by the Duncan multiple ranges test at the $5 \%$ level of probability, using SAS 9.1.

\section{Results and Discussion}

Effect of salt concentration on water holding capacity of $S A P$

Water quality had a considerable effect on the water holding ability by superabsorbent polymer (SAP). Water absorption was highest in distilled water treatment and then decreased with increasing salt concentration. The amount of water retaining capacity by SAP in distilled water experiment was about 7 times more than solution of $1.25 \%$ sodium chloride (Fig. 1). This result indicated that profitability of SAP application is strongly dependent on solute concentration and water quality. These findings are in accordance with the results of Rousta et al. (2013) which reported that SAPs application is not recommended when irrigation water is saline. In a similar study, it was reported that water-holding ability of SAP decreased to $83 \%$ for water with $2,000 \mathrm{mg} \mathrm{l}^{1-1}$ salt concentration compared to distilled water (Rahbar and Banedjschafie, 2009). In the present field study the 
Table 4. Analysis of variance for interaction effects of irrigation management (A) and SAP application (B) on vegetative and reproductive growth of cotton

\begin{tabular}{|c|c|c|c|c|c|c|c|}
\hline $\begin{array}{l}\text { Mean boll } \\
\text { weight }\end{array}$ & $\begin{array}{c}\text { Chlorophyll } \\
\text { index (SPAD) }\end{array}$ & $\begin{array}{l}\text { Number of } \\
\text { reproductive } \\
\text { branches }\end{array}$ & $\begin{array}{c}\text { Number of } \\
\text { lateral branches }\end{array}$ & Plant dry weight & Plant height & $\mathrm{df}$ & Source of variation \\
\hline $6.70^{\circ}$ & $163.5^{* *}$ & $1.16^{\mathrm{ns}}$ & $0.9^{\text {ns }}$ & $41.51^{\mathrm{ns}}$ & $50.4^{\mathrm{ns}}$ & 2 & Replication \\
\hline $3.02^{\mathrm{ns}}$ & $26.1^{\mathrm{ns}}$ & $13.0^{* *}$ & $40.1^{* *}$ & $2366.51^{* *}$ & $258.0^{* \prime}$ & 2 & A \\
\hline $4.97^{\mathrm{ns}}$ & $50.7^{\mathrm{ns}}$ & $0.85^{\mathrm{ns}}$ & $11.5^{* *}$ & $255.52^{\mathrm{ns}}$ & $95.9^{\text {ns }}$ & 4 & $\mathrm{~A}^{*}$ Replication (Ea) \\
\hline $1.00^{\mathrm{ns}}$ & $242.5^{*}$ & $13.06^{*}$ & $26.2^{\prime \prime}$ & $846.61^{*}$ & $70.3^{\text {ns }}$ & 3 & B \\
\hline $25.58^{* *}$ & $157^{\circ}$ & $12.41^{*}$ & $9.4^{*}$ & $1329.26^{* *}$ & $90.7^{\text {ns }}$ & 6 & $\mathrm{~A}^{*} \mathrm{~B}$ \\
\hline 17.30 & 175.5 & 4.5 & 9.0 & 496.12 & 305.7 & 18 & Error $(\mathrm{Eb})$ \\
\hline 58.58 & 815.7 & 45.0 & 97.3 & 5335.55 & 871.2 & 35 & Total \\
\hline $\begin{array}{l}\text { Water use } \\
\text { efficiency }\end{array}$ & Harvest index & Yield per hectare & Yield per plant & $\begin{array}{l}\text { Yield (fiber }+ \\
\text { seed) per boll }\end{array}$ & $\begin{array}{l}\text { Boll number } \\
\text { per plant }\end{array}$ & $\mathrm{df}$ & Source of variation \\
\hline $0.00039^{\text {ns }}$ & $12.72^{\mathrm{ns}}$ & $23812.38^{\mathrm{ns}}$ & $5.36^{\mathrm{ns}}$ & $0.37^{\mathrm{ns}}$ & $7.69^{\circ}$ & 2 & Replication \\
\hline $0.10978^{* *}$ & $434.38^{* \prime}$ & $6179494.38^{* *}$ & $1389.55^{* *}$ & $2.64^{* *}$ & $83.34^{* *}$ & 2 & A \\
\hline $0.02755^{*}$ & $43.61^{\mathrm{ns}}$ & $2657922.77^{* \prime}$ & $598.33^{* \prime}$ & $0.13^{\text {ns }}$ & $8.95^{\mathrm{ns}}$ & 4 & $\mathrm{~A}^{*}$ Replication (Ea) \\
\hline $0.02663^{* *}$ & $12.88^{\mathrm{ns}}$ & $2422049.86^{* *}$ & $454.02^{* *}$ & $5.19^{* *}$ & $26.63^{* \prime}$ & 3 & B \\
\hline $0.02673^{*}$ & $382.27^{* \prime}$ & $2813158.72^{*}$ & $633.11^{*}$ & $3.22^{* *}$ & $71.03^{* \prime}$ & 6 & $A^{*} B$ \\
\hline 0.02366 & 202.33 & 2065264.17 & 464.74 & 2.83 & 15.13 & 18 & Error $(\mathrm{Eb})$ \\
\hline 0.21476 & 212.79 & 1088.22 & 16161702.31 & 3636.14 & 14.40 & 35 & Total \\
\hline
\end{tabular}

Table 5. Means comparison for interaction effects of irrigation management and super absorbent polymer (potassium polyacrylate and polyacrylamide copolymers) application on vegetative growth indices of cotton

\begin{tabular}{|c|c|c|c|c|c|c|}
\hline $\begin{array}{l}\text { Chlorophyll } \\
\text { index (SPAD) }\end{array}$ & $\begin{array}{c}\text { Number of reproductive } \\
\text { branches }\end{array}$ & $\begin{array}{c}\text { Number of } \\
\text { lateral branches }\end{array}$ & $\begin{array}{l}\text { Plant dry } \\
\text { weight }(\mathrm{g})\end{array}$ & $\begin{array}{l}\text { Plant height } \\
(\mathrm{cm})\end{array}$ & $\begin{array}{c}\text { Super absorbent } \\
\left(\mathrm{kg} \mathrm{ha}^{-1}\right)\end{array}$ & Irrigation treatment \\
\hline $49.0^{\text {bcd }}$ & $6.41^{\mathrm{e}}$ & $11.2^{\mathrm{e}}$ & $58.3^{\mathrm{d}}$ & $58.7^{\mathrm{b}}$ & 0 & \multirow{4}{*}{$\begin{array}{l}\text { Control (120 mm evaporation } \\
\text { and } ~ 12 \text { days irrigation intervals) }\end{array}$} \\
\hline $48.5^{b c d}$ & $7.75^{\mathrm{bc}}$ & $13.2^{\mathrm{cd}}$ & $66.6^{\mathrm{cd}}$ & $64.7^{\mathrm{ab}}$ & 30 & \\
\hline $51.6^{\mathrm{ab}}$ & $7.58^{\mathrm{bcd}}$ & $13.8^{\mathrm{cd}}$ & $63.3^{\mathrm{cd}}$ & $65.5^{\mathrm{ab}}$ & 60 & \\
\hline $47.1^{\mathrm{bcd}}$ & $6.58^{\mathrm{e}}$ & $12.4^{\mathrm{de}}$ & $57.1^{\mathrm{d}}$ & $62.4^{\mathrm{ab}}$ & 90 & \\
\hline $43.8^{\mathrm{cd}}$ & $6.83^{\text {cde }}$ & $13.0^{\text {cde }}$ & $80.0^{\mathrm{ab}}$ & $65.7^{\mathrm{ab}}$ & 0 & \multirow{4}{*}{$\begin{array}{l}\text { Moderate water stress }(155 \mathrm{~mm} \\
\text { evaporation and } \sim 15 \text { days } \\
\text { irrigation intervals) }\end{array}$} \\
\hline $56.0^{a}$ & $7.25^{b-e}$ & $14.5^{\mathrm{bc}}$ & $72.5^{b c}$ & $67.8^{\mathrm{a}}$ & 30 & \\
\hline $51.4^{\mathrm{ab}}$ & $9.75^{\mathrm{a}}$ & $16.2^{\mathrm{a}}$ & $80.8^{\mathrm{ab}}$ & $69.2^{a}$ & 60 & \\
\hline $49.6^{b c}$ & $8.16^{\mathrm{b}}$ & $16.1^{\mathrm{ab}}$ & $87.5^{\mathrm{a}}$ & $69.8^{\mathrm{a}}$ & 90 & \\
\hline $43.1^{\mathrm{d}}$ & $6.75^{\mathrm{de}}$ & $12.4^{\mathrm{de}}$ & $66.6^{\mathrm{cd}}$ & $63.1^{\mathrm{ab}}$ & 0 & \multirow{4}{*}{$\begin{array}{l}\text { Sever water stress }(190 \mathrm{~mm} \\
\text { evaporation and } \sim 18 \text { days } \\
\text { irrigation intervals) }\end{array}$} \\
\hline $52.6^{\mathrm{ab}}$ & $5.33^{f}$ & $12.3^{\mathrm{de}}$ & $62.5^{\mathrm{cd}}$ & $59.0^{\mathrm{b}}$ & 30 & \\
\hline $47.9^{\mathrm{bcd}}$ & $7.25^{\mathrm{b}-\mathrm{e}}$ & $13.8^{\mathrm{cd}}$ & $88.3^{\mathrm{a}}$ & $64.3^{\mathrm{ab}}$ & 60 & \\
\hline $49.0^{\mathrm{bcd}}$ & $6.83^{\text {cde }}$ & $12.6^{\mathrm{de}}$ & $87.5^{a}$ & $62.1^{\mathrm{ab}}$ & 90 & \\
\hline
\end{tabular}

All means within a column with the same letter(s) are not significantly different at 0.05 level of probability.

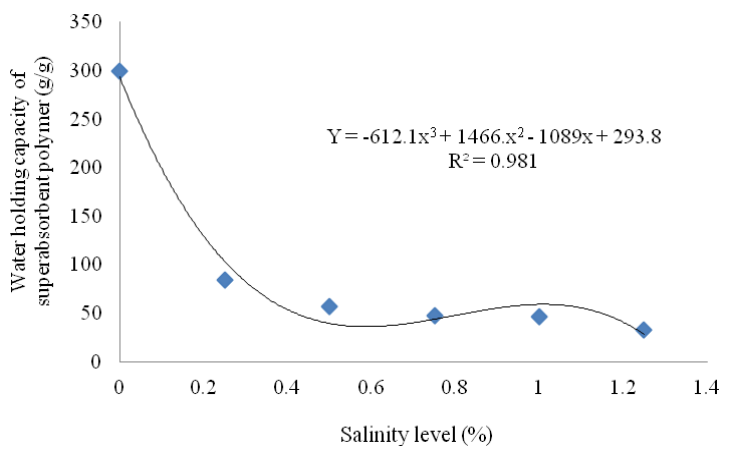

Fig. 1. Effect of water quality on water holding capacity by superabsorbent polymer

amount of monovalent $\left(\mathrm{Na}^{+}, \mathrm{K}^{+}, \mathrm{Cl}^{-}\right)$and divalent $\left(\mathrm{Ca}^{2+}\right.$, $\mathrm{Mg}^{2+}$ ) ions in irrigation water was about $0.042 \%$ (Table $3)$. Therefore, the actual capacity of SAP for distilled water absorption (Fig. 1) was not obtained at real farm conditions.

\section{Vegetative growth indices of cotton}

The interaction effects of deficit irrigation and SAP application were significant on most of the vegetative growth indices of cotton (Table 4). In all irrigation treatments, SAP application improved the vegetative growth properties including plant height, plant dry weight, number of lateral and reproductive branches and chlorophyll index. The highest values of most vegetative growth indices, in different irrigation levels, were obtained at the treatment of $60 \mathrm{~kg} \mathrm{ha}^{-1}$ SAP application (Table 5). In addition, moderate water stress treatment at different levels of SAP improved most of the cotton growth indices (Table 5). Therefore, it is possible to save water resources by increasing irrigation intervals from 120 to $150 \mathrm{~mm}$ pan evaporation in semi-arid regions. The better growth of cotton in moderate water stress compared with control treatment may indicate the inhibitory role of excess moisture and thereby the occurrence of hypoxia in short periods during the growing season.

In similar studies on pear millet (Keshavarz et al., 2012), peanut (Ziaeidoustan et al., 2013), maize (Eneji et al., 2013; Mazen et al., 2015), mustard (Rahmani et al., 2009), bean (Pouresmaeil et al., 2013), corn (Khalili et al., 2011) and soybean (Yazdani et al., 2007) the application of SAP compensated the negative effects of drought 
342

Table 6. Means comparison for interaction effects of irrigation management and SAP application on reproductive growth indices of cotton

\begin{tabular}{|c|c|c|c|c|c|c|c|}
\hline Harvest index & Yield $\left(\mathrm{kg} \mathrm{ha}^{-1}\right)$ & $\begin{array}{l}\text { Yield per } \\
\text { plant }(\mathrm{g})\end{array}$ & $\begin{array}{l}\text { Lint yield per } \\
\quad \text { boll }(\mathrm{g})\end{array}$ & $\begin{array}{l}\text { Mean boll } \\
\text { weight }{ }^{*}(\mathrm{~g})\end{array}$ & $\begin{array}{c}\text { Number of } \\
\text { boll per } \\
\text { plant }\end{array}$ & $\begin{array}{c}\text { Super } \\
\text { absorbent }(\mathrm{kg} \\
\left.\mathrm{ha}^{-1}\right)\end{array}$ & Irrigation intervals (day) \\
\hline $0.54^{a}$ & $4604^{\mathrm{abc}}$ & $69.0^{\mathrm{abc}}$ & $4.96^{\mathrm{cd}}$ & $13.00^{a-d}$ & $10.25^{\text {cd }}$ & 0 & \multirow{4}{*}{$\begin{array}{l}\text { Control (120 mm evaporation } \\
\text { and } \sim 12 \text { days irrigation } \\
\text { intervals) }\end{array}$} \\
\hline $0.43^{\text {def }}$ & $3458^{d}$ & $51.8^{\mathrm{d}}$ & $5.36^{\mathrm{bcd}}$ & $11.30^{\mathrm{d}}$ & $13.08^{b}$ & 30 & \\
\hline $0.52^{\mathrm{ab}}$ & $4804^{\mathrm{abc}}$ & $72.0^{\mathrm{abc}}$ & $5.63^{\mathrm{abc}}$ & $12.36^{\mathrm{bcd}}$ & $11.08^{\mathrm{c}}$ & 60 & \\
\hline $0.53^{\mathrm{ab}}$ & $4333^{a-d}$ & $65.0^{a-d}$ & $5.30^{\mathrm{bcd}}$ & $13.13^{a-d}$ & $11.16^{\mathrm{c}}$ & 90 & \\
\hline $0.44^{\mathrm{cf}}$ & $4124^{\mathrm{bcd}}$ & $61.8^{\mathrm{bcd}}$ & $5.73^{\mathrm{ab}}$ & $11.93^{\text {cd }}$ & $13.91^{b}$ & 0 & \multirow{4}{*}{$\begin{array}{l}\text { Moderate water stress (155 } \\
\text { mm evaporation and } \sim 15 \text { days } \\
\text { irrigation intervals) }\end{array}$} \\
\hline $0.50^{\mathrm{abc}}$ & $4818^{\mathrm{abc}}$ & $72.2^{\mathrm{abc}}$ & $5.26^{\mathrm{bcd}}$ & $14.40^{\mathrm{a}}$ & $10.83^{c}$ & 30 & \\
\hline $0.48^{\text {bcd }}$ & $5027^{\mathrm{a}}$ & $75.4^{\mathrm{a}}$ & $6.20^{\mathrm{a}}$ & $11.86^{\mathrm{cd}}$ & $17.75^{\mathrm{a}}$ & 60 & \\
\hline $0.46^{\text {cde }}$ & $4964^{\mathrm{ab}}$ & $74.4^{\mathrm{ab}}$ & $4.90^{\mathrm{d}}$ & $13.93^{\mathrm{ab}}$ & $13.33^{\mathrm{b}}$ & 90 & \\
\hline $0.44^{-f}$ & $3564^{d}$ & $53.4^{d}$ & $4.00^{e}$ & $12.40^{\mathrm{bcd}}$ & $10.91^{\mathrm{c}}$ & 0 & \multirow{4}{*}{$\begin{array}{l}\text { Sever water stress }(190 \mathrm{~mm} \\
\text { evaporation and } \sim 18 \text { days } \\
\text { irrigation intervals) }\end{array}$} \\
\hline $0.46^{\text {cde }}$ & $3560^{d}$ & $53.4^{\mathrm{d}}$ & $4.83^{\mathrm{d}}$ & $12.30^{\mathrm{bcd}}$ & $08.66^{d}$ & 30 & \\
\hline $0.40^{\text {ef }}$ & $4066 c^{d}$ & $61.0^{\mathrm{cd}}$ & $5.80^{\mathrm{ab}}$ & $13.30^{\mathrm{abc}}$ & $10.91^{c}$ & 60 & \\
\hline $0.39^{f}$ & $3697^{\mathrm{d}}$ & $55.4^{\mathrm{d}}$ & $4.86^{\mathrm{d}}$ & $11.56^{\mathrm{cd}}$ & $10.83^{\mathrm{c}}$ & 90 & \\
\hline
\end{tabular}

stress and suggested that the irrigation intervals of crops could be increased with application of SAP. These materials are hydrophilic and can absorb and retain considerable amounts of water or aqueous solutions. After water availability, these polymers expand between 200-800 times of their original volume. By application of SAP high amounts of water can be collected, stored, and then released gradually for crop growth over duration between two irrigation or rainfalls. Therefore, the application of SAP is a suitable method in irrigation deficit conditions because these materials moderate the negative effect of deficit water and so the irrigation period of a crop can be increased by their application (Dabhi et al, 2013). It has been reported that SAP consumption under drought stress reduces the damage caused by stress in the cytoplasmic membrane and subsequently decrease leakage of cell contents. Moreover, SAP reduces the production of destructive biomarkers and reactive oxygen species by increasing the water availability and thereby antioxidant enzymes activity decreases. These factors reduce the costs implied by supporting plants to neutralize the negative impacts of drought stress and finally enhance plant growth and yield (Rahmani et al.,2009; Islam et al., 2011; Pouresmaeil et al.,2013).

\section{Reproductive growth indices of cotton}

Interaction effects of different levels of irrigation and SAP application were significant on all reproductive growth properties of cotton (Table 4). The highest value of mean number of boll per plant was affected by moderate water stress and $60 \mathrm{~kg} \mathrm{ha}^{-1} S A P$. Experimental factors had no considerable positive impact on mean boll weight, as the amount of this index in no water stress condition was $5 \%$ higher than for sever water stress treatment, while this criterion in $90 \mathrm{~kg} \mathrm{ha}^{-1} \mathrm{SAP}$ was only $4 \%$ higher than control. SAP application inserted a considerable positive impact on cotton yield per boll and per plant in all levels of irrigation, so that application of $60 \mathrm{~kg} \mathrm{ha}^{-1} \mathrm{SAP}$ increased the amounts of mentioned indices by $16 \%$ compared to control. In addition, the amounts of cotton yield per boll and per plant were higher in moderate water stress treatment and then followed by control and sever water stress treatments (Table 6). SAP has a positive effect on cotton yield, especially in moderate and sever water stress conditions. In all levels of water availability, the highest values of cotton yield belonged to $60 \mathrm{~kg} \mathrm{ha}^{-1}$ SAP treatment. Plants watered each aprox. 15 days $(155 \mathrm{~mm}$ pan evaporation) and received $60 \mathrm{kgha}^{-1} \mathrm{SAP}$, produced the highest fiber yield, as the value of this index in mentioned treatment was $17 \%$ higher than the mean of 11 other combination treatments (Table 6). In the present study, the highest SAP application rate $\left(90 \mathrm{~kg} \mathrm{ha}^{-1}\right)$ did not produce the highest cotton yield; this may indicate a negative effect of high levels of SAP on plant yield.
The results of this experiment were in line with those of Rostampour and Ghamari (2014) on corn, Ziaeidoustan et al. (2013) on peanut, Eneji et al. (2013) on maize, Islam et al. (2011) on oat and Rostampour (2013) on sorghum, which reported that SAP had a positive effect on yield and yield component, especially in deficit irrigation condition. Their results revealed that SAP increased the relative water content, leaf water potential and chlorophyll content and reduced stress signals under deficit irrigation. Drought stress has adverse effects on water relations, leaf relative water content, stomatal conductivity, chlorophyll content, photosynthesis, leaf area duration, mineral nutrition, metabolism, growth and yield of plants. This environmental stress cause molecular damage to plants through formation of reactive oxygen species. SAP increases leaf area duration, reduces chlorophyll degradation, regulates the relationship between soil, water and plant and decreases water stress influences on growth of plants and finally increases crops yield (Stewart et al., 2010; Khalili et al., 2011; Dabhi et al., 2013; Ziaeidoustan et al., 2013; Rostampour and Ghamari, 2014). It has been reported that drought stress leads to production of free oxygen radicals, which increase lipid peroxidation and oxidative stress in plants. Application of SAP could hold soil water, making same of it available to plants for reducing oxidative stress, especially under severe drought stress (Islam et al., 2011).

The application of SAP is an effective strategy in areas with low water holding capacity of the soil, where irrigation water and fertilizers often leach below the root zone in a short timeframe, leading to poor water and fertilizer use efficiency. Increasing in resource use efficiencies by SAP application, increases leaf area index and leaf area duration and leads to increasing dry mater accumulation in plants. In addition, physical properties of the soil such as porosity, structure and water-holding capacity might be increased by SAP application. The combination of these factors leads to plant growth improved with limited water supply (Islam et al., 2011; Rostampour, 2013). Considering the several years' durability of SAP in soil, application of sufficient rates of these polymers in different soil water condition could create some benefits regardless of their buying costs (Yazdani et al., 2007).

\section{Water use efficiency of cotton}

Water use efficiency (WUE) was significantly affected by deficit irrigation and SAP rates (Table 4). In all levels of SAP, this index was higher in moderate water stress treatment (Fig. 2). The amounts of WUE in moderate and sever water stress treatments were 25 and $16 \%$ higher than for control, respectively. Moreover, effect of SAP application was positive on WUE, especially in water deficit 


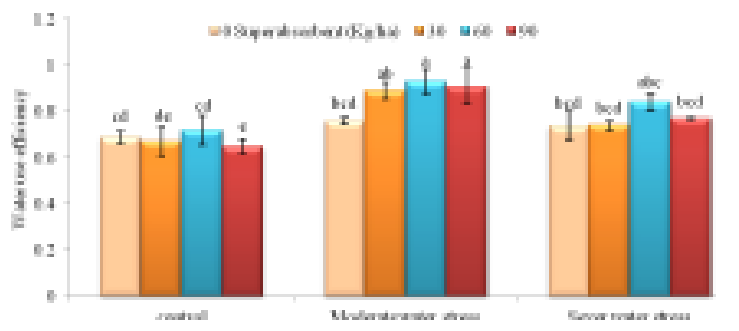

Fig. 2. Interaction effects of deficit irrigation and SAP rates on water use efficiency $\left(\mathrm{kg} \mathrm{m}^{3}\right)$ of cotton

conditions (Fig. 2). By application of $60 \mathrm{~kg} \mathrm{ha}^{-1} \mathrm{SAP}$ the amount of WUE increased by $14 \%$ compared to the control treatment.

Positive effects of deficit irrigation and SAP application on water use efficiency in several experiments have been previously tested. In a study on lettuce and barley, water use efficiency and the interval between field capacity and the onset of wilting was increased considerably in the presence of SAP (Woodhouse and Johnson, 1991). Similar results were obtained by Khalili et al. (2011) on corn, where SAP and water deficit treatments increased water use efficiency. Therefore, for water conservation and optimization of water use efficiency where water scarcity is a common problem, SAP can be used as a water conservator in crop production (Dabhi et al., 2013). In the current study, the amount of yield reduction in sever water stress treatment was smaller with $13 \%$ compared to control, while the amount of water use efficiency in mentioned treatment was $16 \%$ higher than control. These results are consistent with the results of Ghorbani-Nasrabad and Hezarjaribi (2010) and Akbari (2011); in north condition of Iran, supplying about $70 \%$ of cotton water requirement, produced higher water use efficiency and only some yield reduction compared with full irrigation.

It was suggested that in the near future irrigation management will shift from emphasizing production per unit area towards maximizing the production per unit of water consumed (Fereres and Soriano, 2007). It was reported that higher productivity of total used water can be achieved at a water supply level that is lower than the level of water needed for maximum yield. Therefore, deficit irrigation usually has higher water productivity than full irrigation and a considerable value of water can be saved without a significant yield reduction compared to full irrigation. In addition, the risk with deficit irrigation is low because the response curve of crop yield to water supply often has a wide plateau. Nevertheless, deficit irrigation requires more control over the amount and timing of water application than full irrigation. With correct implementation of deficit irrigation programs regarding to the stages when crops are sensitive to water stress, optimal deficit irrigation can be applied with a minimum yield losses compared with full irrigation and, therefore, limited water resources can be used more efficiently in arid areas (Zhang, 2003).

\section{Conclusions}

Based on the results of this experiment, irrigation deficit in arid and semi-arid climates is an effective strategy for suitable utilization of scarce water resources. Although this method may cause some decrease in yield, an appropriate strategy of application will increase the efficiency of water use, without substantial reduction in crop yield. In addition, SAPs are suitable materials for adequate supply of crop water requirement and prevention from water and nutrients loss from the rhizosphere zone. In the present study, the use of polymers in the rate of $60 \mathrm{~kg} \mathrm{ha}^{-1}$ increased the amount of cotton yield by $12 \%$ and the amount of water use efficiency by $14 \%$ compared to control treatment. Overall, irrigation deficit and SAP application are two suitable methods for crop production in areas affected by drought stress.

\section{Acknowledgment}

This research was supported financially by the University of Birjand.

\section{References}

Akbari ND (2011). The effect of different water quantities on yield, water use efficiency and cotton yield function in Mazandaran province, Iran. Journal of Sustainable Agriculture and Production Science 21(1):103-111.

Dabhi R, Bhatt N, Pandit B (2013). Superabsorbent polymersan innovative water saving technique for optimizing crop yield. International Journal of Innovative Research in Science, Engineering and Technology 2(10):5333-5340.

Dai J, Dong H (2014). Intensive cotton farming technologies in China: Achievements, challenges and countermeasures. Field Crops Research 155:99-110.

Eneji AE, Islam R, An P, Amalu UC (2013). Nitrate retention and physiological adjustment of maize to soil amendment with superabsorbent polymers. Journal of Cleaner Production 52:474-480.

Evett RS, Baumhardt RL, Howell AT, Ibragimov NM, Hunsaker JD (2012). Cotton. In: Steduto P (Ed). Crop yield response to water, Rome: Food and Agriculture Organization of the United Nations pp 154-161.

Fereres E, Soriano MA (2007). Deficit irrigation for reducing agricultural water use. Journal of Experimental Botany 58(2):147-159.

Geerts S, Raes D (2009). Deficit irrigation as an on-farm strategy to maximize crop water productivity in dry areas. Agricultural Water Management 96(9):1275-1284.

Ghorbani-Nasrabad G, Hezarjaribi A (2010). Cotton response to deficit irrigation during different growth stages. Journal of Sustainable Agriculture and Production Science 17(4):129-141.

Islam MR, Xue X, Mao S, Ren C, Eneji AE, Hu Y (2011). Effects of water-saving super absorbent polymer on antioxidant enzyme activities and lipid peroxidation in oat (Avena sativa L.) under drought stress. Journal of the Science of Food and Agriculture 91(4):680-686.

Keshavarz L, Farahbakhsh H, Golkar P (2012). The effects of drought stress and super absorbent polymer on morphphysiological traits of pear millet (Pennisetum glaucum). International Research Journal of Applied and Basic Sciences 3(1):148-154.

Khalili MH, Heidaro SA, Nourmohammadi DG, Islam MH, Valizadegan E (2011). Effect of superabsorbent polymer (Tarawat A200) on forage yield and qualitative characters in corn under deficit irrigation condition in Khoy zone (northwest of Iran). Advances in Environmental Biology $5(9): 2579-2587$. 
344

Mazen AM, Radwan DEM, Ahmed AF (2015). Growth responses of maize plants cultivated in sandy soil amended by different super absorbant hydrogels. Journal of Plant Nutrition 38(3):325-337.

Najafinezhad H, Tahmasebi Sarvestani Z, Modarres Sanavy SAM, Naghavi H (2014). Evaluation of yield and some physiological changes in corn and sorghum under irrigation regimes and application of barley residue, zeolite and superabsorbent polymer. Archives of Agronomy and Soil Science 61(7):891-906.

Papastylianou PT, Argyrokastritis IG (2014). Effect of limited drip irrigation regime on yield, yield components, and fiber quality of cotton under Mediterranean conditions. Agricultural Water Management 142:127-134.

Pouresmaeil P, Habibi D, Boojar MMA, Tarighaleslami M (2013). Effect of super absorbent polymer application on chemical and biochemical activities in red bean (Phaseolus volgaris L.) cultivars under drought stress. European Journal of Experimental Biology 3(3):261-266.

Rahbar E, Banedjschafie S (2009). Salinity effects on water uptake ability of superabsorbent polymer and manure. Iranian Journal of Range and Desert Research 16(2):209223.

Rahmani M, Habibi D, Daneshian J, Valadabadi S, Mashhadi ABM, Khalatbari A (2009). The effect of super absorbent polymer on yield and antioxidant enzymes activities of mustard (Sinapis alba L.) under drought stress condition. Journal of Crop Production Research 1(1):23-38.

Razavi SS, Davary K (2014). The role of virtual water in water resource management. Water and Sustainable Development 1:9-18.
Rousta MJ, Soltani M, Besharat N, Soltani V, Salehi M, Rangbar GH (2013). The effect of different levels of superabsorbent polymer and water salinity on soil moisture retention. Iranian Water Research Journal12:241-244.

Rostampour MF (2013). The effect of irrigation regimes and polymer on several physiological traits of forage sorghum. Asian Journal of Agriculture and Food Sciences 1(5):274280.

Rostampour MF, Ghamari M (2014). The effects of water deficit and polymer on some physiological traits in corn (Zea mays L.). Entomology and Applied Science Letters $1(2): 31-39$.

Stewart JM, M Oosterhuis D, Heitholt JJ, Mauney JR (2010). Physiology of cotton. Springer Science \& Business Media.

Woodhouse J, Johnson MS (1991). Effect of superabsorbent polymers on survival and growth of crop seedlings. Agricultural Water Management 20:63-70.

Yazdani F, Alahdadi I, Akbari GA, Behbahani MR (2007). Effect of different rates of superabsorbent polymer (Tarawat A200) on soybean yield and yield components (Glycine max L.). Pajouhesh-va-Sazandegi 75:167-174.

Zhang H (2003). Improving water productivity through deficit irrigation: Examples from Syria, the north China plain and Oregon, USA. In: Kijne JW, Barker R, Molden $\mathrm{D}(\mathrm{Eds})$. Water productivity in agriculture: Limits and opportunities for improvement, $\mathrm{CAB}$ International pp 301-309.

Ziaeidoustan H, Azarpour E, Safiyar S (2013). Study the effects of different levels of irrigation interval, nitrogen and superabsorbent on yield and yield component of peanut. International Journal of Agriculture and Crop Sciences 5(18):2071-2078. 